Macmillan and Co., Ltd., London, have acquired from Cleaver-Hume, Ltd. (a public company with interests in bookselling, paper converting, postal tuition and other fields as well as in publishing), all the shares in its well-known scientific and technical publishing subsidiary, Cleaver-Hume Press, Ltd. This should enable Cleaver-Hume Press to exploit more effectively, as part of a larger economic unit, its valuable special knowledge and contacts, and would also bring to Macmillans a useful addition to their lists in important fields of science and technology. Since the imprint of Cleaver-Hume Press, Ltd. (and its colophon by the late Allan Wyon) are highly esteemed in scientific and technical circles, it is proposed to retain them and to alter the existing organization only so far as may be appropriate for working economies. Publishing policy, too, will remain unchanged.

The long-standing and cordial relationships with the great Philips concern at Eindhoven, for whose Centrex publishing house Cleaver-Hume Press distributes, in the United Kingdom, both books and scientific journals, and with Infosearch, Ltd., London, publishers of scientific books translated from the Russian, will remain undisturbed. Cleaver-Hume Press also announces that it is at present preparing to distribute works, mainly on computers and other aspects of applied physies, issued by the Spartan Publishing Co., Washington, D.C. Mr. P. J. Edmonds will remain managing director of Cleaver-Hume Press and Mr. Daniel Macmillan, chairman of Macmillan and Co., Ltd., will take over the chairmanship. The continuing interest of Cleaver-Hume, Ltd., in publishing has been ensured by the formation of a new Company, to be called Macmillan and Cleaver, Ltd., which will concentrate mainly on books suitable for use with educational courses of the Cleaver-Hume Group, but which, it is hoped, will command a wider market as well. The first book under the new imprint will be Careers Encyclopaedia (Chaffe and Edmondsthird edition), due to be published in February. This title will at first be handled by Macmillan and Co., Ltd., to whom all orders and inquiries should be addressed. Just as Macmillan and Cleaver, Ltd., hope to distribute, in wider fields, books primarily designed for the educational courses, so CleaverHume, Ltd., will still, of course, require for these courses a wide variety of books from other pub. lishers.

\section{Films on Nuclear Energy}

ONE of the tasks of the informal Nuclear Public Relations Contact Group, constituted in Rome on January 20, 1961, was to collect together in one publication brief details of films on nuclear energy which are available in different countries. The first edition was published in September 1961, and a second list, compiled by B. M. Adkins, which is a more accurate and complete edition, has recently been issued (O.E.C.D.: European Nuclear Energy Agency. Nuclear Public Relations: Contact Group. List of Films on Nuclear Energy. Second Edition. Pp. $\mathrm{x}+63$. Paris: O.E.C.D., European Nuclear Energy Agency, 1962). Films from some twentythree countries are listed. Films on the military applications of atomic energy, or on defence against such applications, are not included. The films are grouped under their countries of origin, in reversed chronological order, and the title, sponsor, duration, size, whether black-and-white or coloured, and language of each film are given. A short de- scription of the film's contents is also given in many cases.

\section{The Nitrogen Problem}

A symposium on the "Nitrogen Problem" was held during a session of the National Academy of Sciences, India, in 1960 at the University of Gorakhpur. About fifty papers were presented; they were mainly from research centres in India but included contributions from a few European countries, and they have been published together in two parts of the Proceedings of the National Academy of Sciences, India (31, Section A. Symposium on Nitrogen Problem, Part 1. Pp. 1-164. Rs. 7.50. Part 2. Pp. 165-320. Rs. 7.50. Allahabad: National Academy of Sciences, India, 1961). Various aspects of the nitrogen problem in food production are dealt with, such as the industrial fixation of nitrogen and the manufacture of ammonium compounds and urea, the influence of various factors on biological fixation and on the mobilization of inorganic nitrogen and on fixation under sterile conditions, the composting of waste material, the production of fertilizers from coal, the relative responses in crops to different forms of nitrogen, the loss of nitrogen from the soil and the nitrogen balance of arable land. The urgency of increasing agricultural production in India, as well as in other underdeveloped countries with large populations, and the valuable part that nitrogen can play in raising crop yields are fully stressed. Some statements are of a controversial character, but the large number of statistics and experimental results submitted provide ample testimony to the scope and importance of a serious situation. At the present time the amount of fertilizers used per unit area of cultivated land is no less than 200 times greater in Japan and the Netherlands than in India. Even allowing for differences in climate, soil and agricultural methods, the possibilities of substantially improving food production, were economic difficulties overcome, must be apparent to the most casual observer.

\section{Animal Disease and Human Health}

A series of basic studies supporting the 'Freedom from Hunger Campaign' is being published by the Food and Agriculture Organization and other organizations of the United Nations. Sixteen such studies are contemplated in the series. The subjects cover a wide range and include, for example, the possibilities of increasing world food production, the part marketing can play in increasing productivity, education and training in nutrition, animal diseases and human health, economic development through food, population and food supplies, education in relation to agriculture and economic development, hunger and social policy, malnutrition and disease, weather and food. The latest volume, Animal Disease and Human Health, issued by the Food and Agriculture Organization, has been prepared by Dr. James H. Steele, chief of the Veterinary Public Health Communicable Disease Center, U.S. Public Health Service, and shows that animal health is necessary for the resolution of many human health problems, including freedom from hunger, as well as for the development of sound economies and commerce (Freedom from Hunger Campaign-Basic Study No. 3. Pp. vii +50. Rome: Food and Agriculture Organization of the United Nations; London: H.M.S.O., 1962. 2s. 6d.; 50 cents). Many problems of animal health are amenable to control and eradication. 